\title{
Zanthoxylum armatum DC extracts from fruit, bark and leaf induce hypolipidemic and hypoglycemic effects in mice- in vivo and in vitro study
}

\author{
Fiaz Alam", Qazi Najam us Saqib ${ }^{1}$ and Mohammad Ashraf ${ }^{2}$
}

\begin{abstract}
Background: Zanthoxylum armatum DC is an important medicinal plant of south East Asia, and has been used to treat various ailments in traditional medicine including diabetes. This study investigated the in vitro and in vivo antidiabetic and biochemical effects of extracts of $Z$. armatum in mice.

Method: The extracts of fruit, bark and leaf from $Z$. armatum were tested for a-glucosidase inhibition activity. Albino mice of either sex weighing (26-30 g) assigned into groups. Diabetes was induced by IP injection of alloxan monohydrate $(150 \mathrm{mg} / \mathrm{kg})$. The extracts $(500 \mathrm{mg} / \mathrm{kg})$ and standard (Glibenclamide $10 \mathrm{mg} / \mathrm{kg}$ ) were administered to mice for 15 days. Serum biochemical parameters were monitored for the period of study.

Results: The leaves and bark extracts showed maximum a-glucosidase inhibition (96.61 \pm 2.13 and $93.58 \pm 2.31 \%$ respectively). The extracts treated and the standard treated groups showed significant decrease in the fasting blood glucose levels compared to diabetic control. The effect was more pronounced in mice treated with leaves extract. In the in vivo studies body weights of diabetic mice treated with $Z$. armatum extracts and the standard did not reduced to extent as observed in diabetic control and this difference was significant $(p<0.05)$. There was a significance $(p<0.001)$ improvement in blood hemoglobin, urea, creatinine, cholesterol, and triglycerides of the extracts treated diabetic mice. The extracts showed hypolipidemic effect by reducing the LDL level. The extracts produced no prominent changes in proteins levels.
\end{abstract}

Conclusion: It can be concluded that $Z$. armatum extracts showed excellent antidiabetic potential in vivo and in vitro and could be considered for further appraisal in clinical assessment and drug development.

Keywords: Zanthoxylum Armatum, Antidiabetic, Biochemical parameters, a-glucosidase inhibition

\section{Background}

Natural products and their derivatives have been successful source of bioactive molecules in medicines much before the advancement of other modern therapeutics in the post-genomic era [1]. Studies conducted in several developed countries reported that almost half to two thirds of the population affected with diabetes use complementary and alternative medicine to control the condition [2]. The world health organization has recommended and

\footnotetext{
* Correspondence: alamfiaz@ciit.net.pk

${ }^{1}$ Department of Pharmacy, COMSATS Institute of Information Technology,

Abbottabad -22060, Pakistan

Full list of author information is available at the end of the article
}

encouraged the use of alternative therapy especially in countries where access to the conventional treatment of diabetes is not adequate [3].

Medicinal herbs are expected to have a similar degree of efficacy without the troublesome side effects associated with conventional drug treatment [4]. A multitude of herbs and medicinal plants and some compounds purified from them have been studied for the treatment of diabetes throughout the world as they might provide a basis of new synthetic antidiabetic analogues with potent activity [5]. Plants which have been shown to have hypoglycemic action, act on blood glucose through different mechanisms. Some of them may inhibit endogenous glucose production 
[6] or interfere with gastrointestinal glucose absorption [7] and some may have insulin-like substances [8]. World ethnobotanical information about medicinal plants reports almost 800 plants used in the control of diabetes mellitus [9]. There is much need to explore such resources for the development of new medicines to control or treat diabetes.

Zanthoxylum armatum DC is a small tree almost entirely glabrous with a strong pungent and aromatic smell. Its local name is Timbar or timar (in Hindko), Tejmal, Nepali dhania (in Urdu). It is found in hot valleys of subtropical Himalaya. In Pakistan it is found in Dir, Swat, Hazara, Murree and Poonch hills and in Jhelum. The seeds and bark are used as an aromatic tonic in fever, dyspepsia and in cholera. The fruit as well as branches and thorn are used as remedy for toothache, also as stomachic and carminative and employed as fish toxin [10]. Various parts of this $Z$. armatum are used in the preparation of tooth powder and medicinal preparations. The studies on this plant during the last few decades show that these plants contain various useful pharmacological active compounds [11].

The evidences are available where $Z$. armatum leaves water extract was tested for anti-diabetic potential in animals. The experiments demonstrated that $Z$. armatum water extract possess anti-diabetic activity in in-vivo procedure using mice [12]. Similarly, in another experiment the hydromethanolic extract of bark of $Z$. armatum was evaluated for its antidiabetic activity in streptozocininduced diabetes in rats. The total cholesterol, triglycerides, low density lipoprotein, very low density lipoprotein were also monitored [13]. So, there are enough evidence available for testing $Z$. armatum for anti-diabetic potentials in animal models. Keeping in view the importance of this plant genus in management of diabetes this work was carried out to investigate the potential of $Z$. armatum against diabetes.

\section{Methods}

\section{Chemicals}

Chemicals used in experiments were of analytical with high purity grade procured from standard commercial sources. Organic solvents: Methanol (CAS No. 67-56-1.), Diethyl ether (CAS 60-29-7), Ethanol (CAS No. 64-17-5), Ethyl acetate (CAS 141-78-6), Chloroform (CAS 67-66-3), n-Hexane (CAS 110-54-3) from Merck (Germany). Glibenclamide (CAS Number: 10238-21-8), Alloxan monohydrate (CAS Number: 2244-11-3) from Sigma Aldrich (CAS Number: 2244-11-3) from Fluka chemicals. Glucose 5\% Normal Saline, 0.9\% from Shahzeb Pharma, Pakistan. Cholesterol kit, Triglycerides kit, Hb Kit from Erba. Acarbose (CAS Number: 56180-94-0), a-glucosidase (CAS Number: 9001-42-7), Sigma-Aldrich Co., St. Louis, USA.

\section{Instruments}

Feeding Tube Syringes/butterfly needle from Pharmax, (Pakistan). Weighing balance from Sartorius (GE412 scale). Glucometer from Accucheck (Model Aviva by Roche, Germany). Cylomixer (CM 101 plus) from Remi (India). Rotary evaporator Laborota 4000 from Heidolph (Germany).

\section{Plant material}

Five $\mathrm{kg}$ of each of leaves, bark and fruit of Z. armatum were collected form Tanawal area of KPK Pakistan in the month of August, 2013. After authentication from plant taxonomist Manzoor Hussain and specimen voucher (PB025) was deposited in the herbarium of the Post graduate college, Abbottabad. Each part of the plant was washed under running water and dried in shade at room temperature and was ground to coarse powder. The powder drug was stored in air tight and light resistant container before extraction.

\section{Preparation of plant extracts}

The powder material (100 g) of the fruit, bark and leaves was extracted with methanol using soxhlet extractor for $20 \mathrm{~h}$ each. It was filtered through a Whatman Grade-I filter paper. The filtrate was evaporated on a vacuum rotary evaporator under reduced pressure at $40{ }^{\circ} \mathrm{C}$. The desiccator was used to remove the remaining moisture, and finally the extracts were stored in air tight containers at $4{ }^{\circ} \mathrm{C}$ for further use.

\section{Experimental animals}

Healthy adult albino mice (26-30 g) of either sex were selected for the study. The animals were obtained from National Institute of Health (NIH) and then bred in Animal house of CIIT Abbottabad. Mice were housed in polypropylene cages $(47 \times 34 \times 20 \mathrm{~cm})$ lined with husk (renewed every $24 \mathrm{~h}$ ). They were given a standard diet and water ad libitum. The pellet diet consisted of $23 \%$ protein, $5 \%$ lipids, $4 \%$ crude fiber, $8 \%$ ash, $1 \%$ calcium, $0.6 \%$ phosphorus, $3.4 \%$ glucose, and $5 \%$ nitrogen-free extract (carbohydrates). After experiment the animals were euthanized by applying three times the dosage of pentobarbital through intraperitoneal injection. The approval number PHM-Eth/CF-M04/11-24 of the Research, Ethical Committee (REC), department of Pharmacy, CIIT, Abbottabad was taken before the animal studies were conducted.

\section{a-glucosidase inhibitory assay}

The assay was carried out according to the method described by [14] with slight modification. All the samples were dissolved in DMSO. An enzyme solution containing $\alpha$-glucosidase $(0.8$ units $/ \mathrm{ml})$ in $50 \mathrm{mM}$ phosphate buffer with $\mathrm{pH} 7$, containing $100 \mathrm{mM} \mathrm{NaCl}$ was made 
immediately before use. The solution was kept on ice during the experiment. The substrate, pNP-G $(0.7 \mathrm{mM})$ in phosphate buffer, was prepared fresh before use. The test solution $(20 \mu \mathrm{L})$ and enzyme solution $(80 \mu \mathrm{L})$ was pre-incubated for $5 \mathrm{~min}$ at $37{ }^{\circ} \mathrm{C}$. The reaction was initiated with $1.9 \mathrm{~mL}$ of substrate solution and incubated for fifteen minutes at $37{ }^{\circ} \mathrm{C}$. The reaction was stopped by adding $2.0 \mathrm{~mL}(0.5 \mathrm{M})$ aqueous Tris solution, and the absorbance of PNP released from PNP-G was measured at $400 \mathrm{~nm}$. $20 \mu \mathrm{L}$ DMSO was kept as blank (Without addition of test solution). Acarbose was used as a + tive control. Analysis was carried out in triplicates, and the results were calculated as \pm SEM.

Percent $\alpha$-glucosidase inhibition was calculated as follows: $(1-\mathrm{B} / \mathrm{A}) \times 100$, where $\mathrm{A}$ is the absorbance of control and $\mathrm{B}$ is the absorbance of samples containing extracts.

\section{Oral glucose tolerance test}

Before the induction of diabetes the oral glucose tolerance test was performed in overnight fasted (18 h.) normal mice as per [15]. Healthy mice were randomly selected and distributed into five groups $(n=6)$. Glucose ( $2 \mathrm{~g} / \mathrm{kg}$ b.w.) was fed. Blood was taken out from the tail vein at $0,60,90,120$ and 150 min of glucose administration and glucose levels were estimated.

\section{Induction of diabetes and experimental design}

Antidiabetic activity was carried out on selected healthy albino mice [16]. The experiments were carried out in accordance with the National Institute of Health guidelines of care and use of laboratory animals [17]. Diabetes was induced in mice using freshly prepared solution of alloxan monohydrate dissolved in normal saline $(0.9 \%$ $w / v$ of $\mathrm{NaCl}$ ). For inducing diabetes, the mice were kept on fasting for $12 \mathrm{~h}$ and were given a single IP injection of alloxan monohydrate $(150 \mathrm{mg} / \mathrm{kg}$ b. wt.). To prevent fatal hypoglycemia initially due to massive pancreatic insulin release, the mice were provided with $5 \%$ glucose solution after six hours supplied in water bottles in their cages for next $24 \mathrm{~h}$. Animal were kept at room temperature $\left(27 \pm 2{ }^{\circ} \mathrm{C}\right)$ and humidity $(55 \pm 5 \%)$ and a 12 h' cycle of light and dark. After $72 \mathrm{~h}$, the glucose level of the fasting animals was measured. After acclimatization, the animals were separated into following groups (six mice in each group); Groups A, Normal control treated with saline; B, Diabetic control; C, Diabetic mice treated with $500 \mathrm{mg} / \mathrm{kg}$ body weight of fruit extract; D, Diabetic mice treated with $500 \mathrm{mg} / \mathrm{kg}$ body weight of bark extract; E, Diabetic mice treated with $500 \mathrm{mg} / \mathrm{kg}$ body weight of leaves extract F, Normal mice given $500 \mathrm{mg} / \mathrm{kg}$ of Gt-MeOH extract and G, reference control treated with glibenclamide $(10 \mathrm{mg} / \mathrm{kg})$. An identification mark was given to the mice of each group on the tail with permanent marker. Each of mice was weighed and the doses were calculated accordingly. The extract was given orally. All the groups were given respective treatments daily for 15 days. To check the effect of the extracts on the weight of animals, weight of the mice was recorded prior to the administration of the extracts and at the end of the study as well i.e. on the 15th day.

The blood samples were collected (in glass tubes) and left for $1 \mathrm{~h}$ at $37^{\circ} \mathrm{C}$ to allow to clot. The blood was collected using capillary tubes into Eppendorf Tubes ${ }^{\ominus}$ containing heparin for analysis of plasma profile. Using a glass Pasteur, carefully, the clot was loosened from the sides of the tube. The serum was centrifuged at $5000 \mathrm{rpm}$ for $5 \mathrm{~min}$ at $4{ }^{\circ} \mathrm{C}$. The serum was removed from the clot by gently pipetting off into a clean tube using a micropipette. The serum was labeled with the animal number and the estimations were made [18].

\section{Biochemical analysis}

The blood sugar level was measured using Accu-Chek ${ }^{\circledR}$ Active test strips in Accu-Chek ${ }^{\odot}$ Active test meter by collecting the blood from the vein of mice tail. Total cholesterol and triglycerides were assayed using the protocol of [19].The level of serum urea and creatinine were assayed using the protocol given by [20]. Total proteins were assayed using protocol described by [21]. HDL and LDL were measured by the protocol given by [22].

\section{Statistical analysis}

All the values including body weight, fasting blood sugar, and biochemical estimations were expressed as mean \pm standard deviation (S.D.) and analyzed for ANOVA Dunnet's test. Differences between groups were considered significant at $p<0.001$ and $p<0.05$ levels. The normal control was compared with the normal extract treated groups while diabetic control was compared with the diabetic extract treated and Glibenclamide treated groups.

\section{Results}

\section{a-glucosidase inhibitory activity}

The extracts $\mathrm{Zf}, \mathrm{Zb}$ and $\mathrm{Zl}$ from $\mathrm{Z}$. armatum showed significant inhibition of $\alpha$-glucosidase enzyme in an invitro antidiabetic assay. The extracts $\mathrm{Zl}$ and $\mathrm{Zb}$ inhibited the enzyme with percentage and $\mathrm{IC}_{50}$ values of $96.61 \pm$ $2.13\left(\mathrm{IC}_{50}=47.87 \pm 0.45\right)$ and $93.58 \pm 2.31 \% \quad\left(\mathrm{IC}_{50}=\right.$ $21.82 \pm 0.87)$ respectively. The fruit extract also showed very good activity and inhibited the enzyme with percentage inhibition and $\mathrm{IC}_{50}$ values of $83.76 \pm 3.01 \%$ $\left(\mathrm{IC}_{50}=31.62 \pm 0.67\right)$.

\section{Effect on body weight}

The effect of extracts of $Z$. armatum on body weight of mice is shown in Table 1 . The table for the body weight 
Table 1 Effect of extracts of Zanthoxylum armatum and standard drug Glibenclamide on body weight of normal and alloxan monohydrate induced diabetic mice

\begin{tabular}{|c|c|c|c|c|}
\hline \multirow[t]{2}{*}{ Groups } & \multicolumn{4}{|c|}{ Body weight in grams } \\
\hline & Before treatment & After 7 days & After 15 days & $\%$ Variation \\
\hline Normal & $27.67 \pm 2.3$ & $30.83 \pm 4.3$ & $34.33 \pm 6.3$ & $10.77 \%$ \\
\hline Diabetic control & $32 \pm 1.8$ & $28 \pm 3.0$ & $25 \pm 3.8^{* *}$ & $12.39 \%$ \\
\hline Normal Zf treated & $29.67 \pm 2.33$ & $31.33 \pm 2.50$ & $33.83 \pm 2.04^{* *}$ & $6.62 \%$ \\
\hline Diabetic Zf treated & $31 \pm 1.1$ & $25 \pm 1.8$ & $26 \pm 2.4$ & $12.81 \%$ \\
\hline Normal Zb. Treated & $29.67 \pm 2.33$ & $31.00 \pm 2.09$ & $33.00 \pm 2.09^{* *}$ & $5.37 \%$ \\
\hline Diabetic Zb treated & $30.00 \pm 2.82$ & $28.83 \pm 3.83$ & $27.27 \pm 3.06$ & $4.77 \%$ \\
\hline Normal ZI treated & $30.00 \pm 1.78$ & $31.00 \pm 1.67$ & $32.83 \pm 1.83$ & $4.59 \%$ \\
\hline Diabetic $\mathrm{Zl}$ treated & $29.00 \pm 2.75$ & $21.67 \pm 2.94$ & $24.50 \pm 1.04$ & $14.96 \%$ \\
\hline Diabetic Glibenclamide $(10 \mathrm{mg} / \mathrm{kg})$ treated & $30 \pm 1.8$ & $30.01 \pm 1.7$ & $29.3 \pm 1.8$ & $13.39 \%$ \\
\hline
\end{tabular}

Data represented as mean \pm S.D. values of 6 animals each ${ }^{*} p<0.001,{ }^{* *} p<0.05$ (One wayANOVA, Dunnet's t-test, Graph pad prism software). Normal control was compared with extract treated normal groups. The diabetic control was compared with extract treated diabetic groups and standard

changes shows that there is significant increase in the body weight of the extract and standard treated groups when compared to the diabetic group $(p<0.05)$ over the period of 15 days. The diabetic group showed decrease in the body weight. The groups of normal mice treated with extracts were compared with diabetic control group for changes in body weights. The extracts of $Z$. armatum fruit $(\mathrm{Zf})$, bark $(\mathrm{Zb})$ and leaves $(\mathrm{Zl})$ showed a significant increase in body weights $(\mathrm{p}<0.05)$ of normal mice as compared with diabetic group treated with extract. However, leaves extract showed comparatively less effects on body weights of normal as well as diabetic treated groups.

\section{Effect of different extracts of Zanthoxylum armatum on blood glucose levels}

The induction of diabetes has caused significant initial increase in the fasting blood glucose levels of all the groups. The diabetic control group shows significant increase throughout the study period as compared with the normal control group $(p<0.001)$. However, the extracts treated groups and the standard treated group shows significant decrease in the fasting blood glucose levels as compared with diabetic control which was determined on the 0th, 3rd, 6th, 9th, 12th and 15th day of the experiment. The effect was more pronounced in standard $(10 \mathrm{mg} / \mathrm{kg})$ group, which shows significance decrease in blood glucose level $(p<0.001)$ from 3rd to 15 th day of the experiment.

The methanol extract of $Z$. armatum fruit $(\mathrm{Zf})$ caused the significant $(p<0.05)$ decrease in blood glucose level of normal group of mice on 15 th day. Zf proved very effective and decrease the blood glucose level diabetic mice significantly $(p<0.001)$ from 3 rd to 15 th day of the experiment. The methanol extract of $Z$. armatum bark (Zb) showed no significance activity on normal group of mice. $\mathrm{Zb}$ also showed significant $((p<0.001)$ activity when compared with diabetic control. The methanol extract of $Z$. armatum leaves $(\mathrm{Zl})$ effect was normal on normal group of mice and no significant effect was observed. $\mathrm{Zl}$ showed significant activity $(\mathrm{p}<0.001)$ on blood glucose level of the diabetic mice from 3rd to final day of the experiment when compared with diabetic control. The effect of $\mathrm{Zl}$ on blood glucose level of diabetic mice was comparable with the standard drug (Glibenclamide). All the results are tabulated in Table 2 .

\section{Effect of different extracts of Zanthoxylum armatum on biochemical parameters \\ $\mathrm{Hb}$}

The effect of alloxan monohydrate on mice hemoglobin level was significant $(p<0.001)$ and it reduced the hemoglobin level to $6.278 \pm 0.45$ when compared with normal group $(9.453 \pm 0.4)$.

All the normal groups treated with extracts $(\mathrm{Zf}, \mathrm{Zb}$ and $\mathrm{Zl})$ showed no significance fluctuation of hemoglobin level when compared with the normal control. However, there is a significance $(p<0.001)$ improvement in blood hemoglobin of the diabetic mice treated with the extracts and standard drug (Glibenclamide $10 \mathrm{mg} / \mathrm{kg}$ ) when compared with diabetic control. All the results are tabulated in Table 3 .

\section{Total proteins}

The alloxan monohydrate treated diabetic group of mice (diabetic control) showed significance $(\mathrm{p}<0.001)$ decrease in total proteins level when compared with normal control. When observed the effect of all the extracts ( $\mathrm{Zf}, \mathrm{Zb}$ and $\mathrm{Zl}$ ) and standard drug on normal and diabetic mice, no prominent change in proteins level was noted in any case. All the results are tabulated in Table 4.

\section{Urea}

Alloxan monohydrate treated diabetic mice showed a significance $(p<0.001)$ increase in serum urea level of 
Table 2 Effect of extracts of Zanthoxylum armatum and standard drug Glibenclamide on glucose level of normal and alloxan induced diabetic mice

\begin{tabular}{|c|c|c|c|c|c|c|c|}
\hline \multirow[t]{2}{*}{ Groups } & \multicolumn{7}{|c|}{ Glucose level (mg/dl) } \\
\hline & $\mathrm{O}^{\text {th }}$ day & 3rd day & 6th day & 9th day & 12th day & 15th day & $\%$ variance \\
\hline Normal control & $110.5 \pm 14$ & $99.83 \pm 17$ & $99.33 \pm 18$ & $102.2 \pm 28$ & $107.5 \pm 3$ & $109.2 \pm 2$ & $4.69 \%$ \\
\hline Diabetic control & $333.7 \pm 1^{*}$ & $344.0 \pm 2^{*}$ & $345.3 \pm 22^{*}$ & $335.8 \pm 40^{*}$ & $358.0 \pm 20^{*}$ & $374.7 \pm 16^{*}$ & $6.80 \%$ \\
\hline Normal Zf treated & $111.2 \pm 13$ & $107.5 \pm 15$ & $104.5 \pm 16$ & $98.67 \pm 14$ & $98.33 \pm 14$ & $78.83 \pm 34^{* *}$ & $11.46 \%$ \\
\hline Diabetic Zf treated & $334.2 \pm 44.6$ & $298.0 \pm 1^{*}$ & $255.8 \pm 25^{*}$ & $250.0 \pm 30^{*}$ & $234.8 \pm 2^{*}$ & $215.8 \pm 30^{*}$ & $16.48 \%$ \\
\hline Normal Zb. Treated & $114.0 \pm 15$ & $109.7 \pm 13$ & $112.7 \pm 13$ & $101.3 \pm 12$ & $94.67 \pm 10$ & $94.5 \pm 12$ & $8.47 \%$ \\
\hline Diabetic Zb treated & $279.8 \pm 36$ & $265.8 \pm 3^{*}$ & $259.2 \pm 38^{*}$ & $252.2 \pm 35^{*}$ & $246.3 \pm 3^{*}$ & $239.2 \pm 33^{*}$ & $5.65 \%$ \\
\hline Normal ZI treated & $106.8 \pm 17$ & $105.3 \pm 15$ & $108.8 \pm 17$ & $99.6 \pm 14$ & $100.2 \pm 11$ & $98.83 \pm 14$ & $4.09 \%$ \\
\hline Diabetic Zl treated & $325.2 \pm 26$ & $234.0 \pm 3^{*}$ & $188.8 \pm 36^{*}$ & $154.0 \pm 23^{*}$ & $147.5 \pm 2^{*}$ & $123.7 \pm 18^{*}$ & $37.95 \%$ \\
\hline Diabetic Glibenclamide treated & $320.7 \pm 22$ & $271.5 \pm 18^{*}$ & $215.7 \pm 18^{*}$ & $154.2 \pm 18^{*}$ & $163.0 \pm 1^{*}$ & $136.3 \pm 17^{*}$ & $34.84 \%$ \\
\hline
\end{tabular}

Data represented as mean \pm S.D. values of 6 animals each ${ }^{*} p<0.001,{ }^{* *} p<0.05$ (One way ANOVA, Dunnet's t-test, Graph pad prism software). Normal control was compared with normal control. and extract treated. The Diabetic control was compared with diabetic extract treated and standard

mice. Normal mice treated with the extracts for 15 days showed no prominent change in urea level when compared with the normal control. When compared with the diabetic control the extracts $(\mathrm{Zf}, \mathrm{Zb}$ and $\mathrm{Zl})$ treated groups after 15 days of treatment showed a significance $(p<0.001)$ improvement (decrease) of urea level. The standard drug also showed similar results.

\section{Creatinine}

When compared with the normal group the diabetic control group showed a significant $(p<0.05)$ increase in serum creatinine level. The normal mice groups treated with extracts ( $\mathrm{Zf}, \mathrm{Zb}$ and $\mathrm{Zl}$ ) showed no prominent effect on serum creatinine level. However, a significance $(p<$ $0.05)$ decrease in serum creatinine level was observed with extracts ( $\mathrm{Zf}$ and $\mathrm{Zb})$, less significance $(p<0.001)$ with $\mathrm{Zl}$ and standard drug glibenclamide when compared with the diabetic control. The results are tabulated in Table 5.

Table 3 The effect of extracts of Zanthoxylum armatum and standard drug Glibenclamide on $\mathrm{Hb}$ level of normal and diabetic mice

\begin{tabular}{lc}
\hline Group & $\mathrm{Hb}(\mathrm{g} / \mathrm{dL})$ \\
\hline Normal & $9.453 \pm 0.4$ \\
Diabetic & $6.278 \pm 0.45^{*}$ \\
Normal Zf treated & $9.09 \pm 0.84$ \\
Diabetic Zf treated & $9.608 \pm 0.28^{*}$ \\
Normal Zb. Treated & $9.020 \pm 0.85$ \\
Diabetic Zb treated & $8.26 \pm 0.25^{*}$ \\
Normal Zl treated & $9.17 \pm 0.89$ \\
Diabetic Zl treated & $8.30 \pm 0.30^{*}$ \\
Diabetic Glibenclamide treated & $8.20 \pm 0.27^{*}$ \\
\hline $\begin{array}{l}\text { Data represented as mean } \pm \text { S.D. values of } 6 \text { animals each }{ }^{*} p<0.001 \text { (One way } \\
\text { ANOVA, Dunnet's t-test, Graph pad prism software). Normal control was } \\
\text { compared with normal control and extract treated. The Diabetic control was } \\
\text { compared with diabetic extract treated and standard }\end{array}$
\end{tabular}

\section{TC and TG}

There was no significance difference in total cholesterol (TC) and triglyceride (TG) levels when normal control was compared with the normal extract ( $\mathrm{Zf}, \mathrm{Zb}$ and $\mathrm{Zl}$ ) treated groups. The diabetic control showed hyperlipidemia compared with normal control as indicated by increased level of TC and TG in diabetic mice. The extracts ( $\mathrm{Zf}, \mathrm{Zb}$ and $\mathrm{Zl}$ ) and standard treated groups significantly decreased the serum level of cholesterol and triglycerides compared to the diabetic control group $(p<0.001)$. The results of hypolipidemic potential of all the plant extracts were comparable to standard drug (Glibenclamide $10 \mathrm{mg} / \mathrm{mL}$ ) Figs 1 and 2 .

\section{$H D L$}

Alloxan monohydrate rendered diabetic groups showed a significant $(p<0.001)$ decrease in high density lipoproteins (HDL) serum level compared to the normal control.

Table 4 The effect of extracts from Zanthoxylum armatum and standard drug Glibenclamide on total protein level of normal and diabetic mice

\begin{tabular}{lc}
\hline Group & Total proteins $(\mathrm{mg} / \mathrm{dL})$ \\
\hline Normal & $5.367 \pm 0.68$ \\
Diabetic & $4.03 \pm 0.51^{*}$ \\
Normal Zf treated & $5.58 \pm 0.66$ \\
Diabetic Zf treated & $4.13 \pm 0.49$ \\
Normal Zb. treated & $5.00 \pm 0.92$ \\
Diabetic Zb treated & $4.11 \pm 0.41$ \\
Normal Zl treated & $5.51 \pm 0.71$ \\
Diabetic Zl treated & $4.11 \pm 0.37$ \\
Diabetic Glibenclamide treated & $5.53 \pm 0.71$
\end{tabular}

Data represented as mean \pm S.D. values of 6 animals each ${ }^{*} p<0.001$ (One way ANOVA, Dunnet's t-test, Graph pad prism software). Normal control was compared with normal control and extract treated. The Diabetic control was compared with diabetic extract treated and standard 
Table 5 The effect of extracts of Zanthoxylum armatum and standard drug Glibenclamide on serum urea and creatinine level in normal and diabetic mice

\begin{tabular}{lcc}
\hline Groups & Urea $(\mathrm{m} \mathrm{mol} / \mathrm{L})$ & Creatinine $(\mu \mathrm{mol} / \mathrm{L})$ \\
\hline Normal & $5.16 \pm 0.42$ & $28.20 \pm 1.82$ \\
Diabetic & $17.70 \pm 0.85^{*}$ & $37.38 \pm 0.80^{* *}$ \\
Normal Zf treated & $4.88 \pm 0.33$ & $29.55 \pm 1.04$ \\
Diabetic Zf treated & $12.10 \pm 1.52^{*}$ & $34.30 \pm 0.69^{* *}$ \\
Normal Zb treated & $4.71 \pm 0.45$ & $29.52 \pm 1.06$ \\
Diabetic Zb treated & $12.95 \pm 0.56^{*}$ & $34.5 \pm 0.73^{* *}$ \\
Normal Zl treated & $4.13 \pm 0.27$ & $29.55 \pm 1.01$ \\
Diabetic Zl treated & $13.70 \pm 1.44^{*}$ & $32.03 \pm 1.33 *$ \\
Diabetic Glibenclamide treated & $17.70 \pm 0.85^{*}$ & $32.87 \pm 2.37^{*}$ \\
\hline
\end{tabular}

Data represented as mean \pm S.D. values of 6 animals each ${ }^{*} p<0.001,{ }^{* *} p<0.05$ (One way ANOVA, Dunnet's t-test, Graph pad prism software). Normal control was compared with normal control and extract treated. The Diabetic control was compared with diabetic extract treated and standard

All the extracts and standard drug in the course of treatment for 15 days showed a significance improvement of HDL level in diabetic mice compared to the diabetic control $((p<0.001)$ (Fig. 3).

\section{$L D L$}

In contrast to HLD level, the low density lipoprotein (LDL) was significantly increased in diabetic control compared to normal control. All the extracts and standard drug treated groups showed decreased LDL level significantly $(p<0.001)$ compared to the diabetic control after 15 days of treatment thereby showing hypolipidemic effect (Fig. 4).

\section{Discussions}

Diabetes has a high prevalence of morbidity and mortality in the world. It is a disease that is not curable but it can be control. A variety of treatments including synthetic drugs, natural medicine and dietary supplements are used to control the diabetes and its related complications.
The use of natural products is very common in the less developed world where these remedies are more accessible and affordable than modern pharmaceuticals. As the research in medicinal plants progressed, more evidences about the effectiveness and safety are available and this is the reason that the use of herbal products as diabetic remedies have increased in the developed world. The incidence of type 2 diabetes mellitus has increased globally which imposed high cost to health services around the world. Due to this fact, there is an increase interest in research in the field of ethnopharmacology for the last two decades and the main focus has been on diabetes. One of the reasons which motivated the research into medicinal plants for diabetic treatment is the lack of effectiveness of the synthetic drug therapy and its consequence of adverse effects [23].

There is a long history of use of medicinal and dietary plants for the treatment of diabetes. Few examples included are, nopal (prickly pear cactus), fenu-greek, karela (bitter melon), gymnema, ginseng, tronadora, chromium, and alpha-lipoic acid. The popularity of these products varies among people of different ethnicities. Nopal is the most commonly used herbal hypoglycemic among persons of Mexican descent. Karela is more commonly used by persons from Asian countries. Some of these agents have gained universal appeal. The studies conducted so far have revealed single or multiple mechanisms of action. Among several of these, high soluble fiber content is a contributing factor. Based on the available evidences, several natural products in common use can lower blood glucose in patients with diabetes [24].

Recently several authors have worked on medicinal plants for their potential role as antidiabetic agents [25-27]. In order to identify the plants with antidiabetic properties various plants have been tested in-vivo using animal models, for example rats, mice, rabbits, against the complications caused by inducers of diabetes, and it has been established that many plants possess the potential to lower the blood glucose levels and besides help in improving other diabetic complications [28]. The

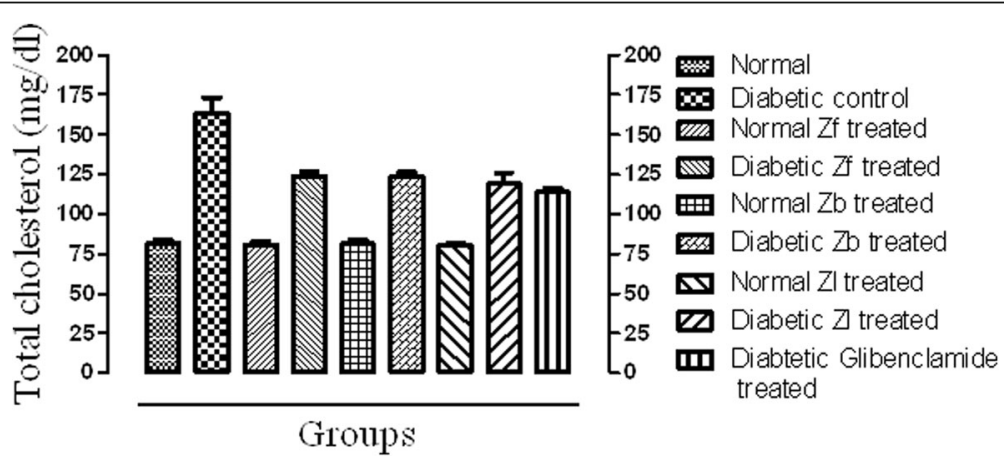

Fig. 1 Effect of extracts and standard drug on total cholesterol $(\mathrm{mg} / \mathrm{dl})$ level of normal and alloxan monohydrate induced diabetic mice 


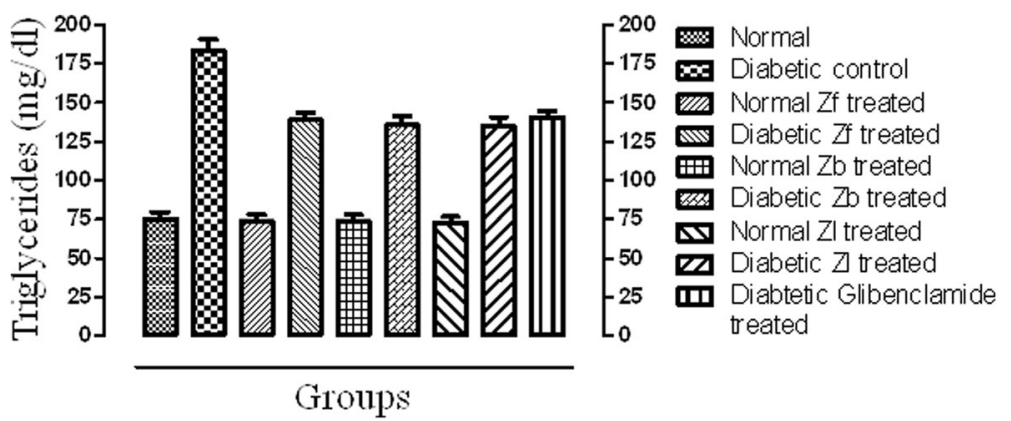

Fig. 2 Effect of extracts and standard drug on serum triglycerides ( $\mathrm{mg} / \mathrm{dl})$ level of normal and alloxan monohydrate induced diabetic mice

antidiabetic effects might be achieved by facilitating insulin release from pancreatic ß-cells, inhibition of glucose absorption in GIT, stimulating glycogenesis in liver and/ or increasing glucose utilization by the body [29].

There are reports of antidiabetic studies on Zanthoxylum plants for example Zanthoxylum zanthoxyloides leaves exhibits antidiabetic and hypolipidemic effects [30]. Similarly, Z. armatum bark showed antidiabetic activity on streptozosin induced diabetes in rats [13].

$\alpha$-glucosidase is the key enzyme in the digestion of carbohydrates in the surface membranes of intestine. $\alpha$ glucosidase inhibitors suppress the postprandial hyperglycemia by retarding the liberation of D-glucose of oligosaccharides and disaccharides from dietary complex carbohydrates and therefore delay the glucose absorption [31]. Acarbose, one of such inhibitors are approved in management of type 2 diabetes and for the treatment of obesity [32]. It is necessary to search for more effective and safe $\alpha$-glucosidase inhibitors from natural materials, in order to develop antidiabetic agents. The extracts of $Z$. armatum showed very significant activity against alphaglucosidase and all the extract inhibited the enzyme with low concentration comparable with the standard drug acarbose. In vivo studies, the extracts of $Z$. armatum lower the glucose level of alloxan induced diabetes to significant level.

In our studies the methanol extract of $Z$. armatum (fruit, bark and leaves) at a dose of $500 \mathrm{mg} / \mathrm{kg}$ showed significant effect on the glucose tolerance of mice and the extracts also showed reduction in the fasting blood glucose levels of the norm glycemic mice, thus revealing the hypoglycemic nature of the extracts. The effect was more pronounced for the methanol extract of $Z$. armatum leaves.

As the insulin is produced in the $\beta$-cells of islets of Langerhans. Alloxan monohydrate caused the destruction of $\beta$-cells and stops the production of Insulin and results in induction of diabetes. Therefore, in this case the extracts might have produce the hypoglycemic effect by a mechanism not involving insulin [6].

The hypoglycemic effect of the extracts in hyperglycemic mice was studied during 15 days treatment. The difference observed between the initial and final fasting serum glucose levels of extract treated hyperglycemic mice revealed antihyperglycemic effect of the extracts (Zf, $\mathrm{Zb}$ and $\mathrm{Zl}$ ) throughout the period of study. The effect of the extracts was compared to that of reference standard (glibenclamide) and was found to be significant statistically.

It is common observation that the in diabetes mellitus the level of serum lipids are usually high. This elevation can be risk of coronary heart disease. The hyperlipidemia that characterizes the diabetic conditions may be regarded as a result of the uninhibited actions of lipolytic hormones on the fat depots. Therefore, a drug therapy or a dietary

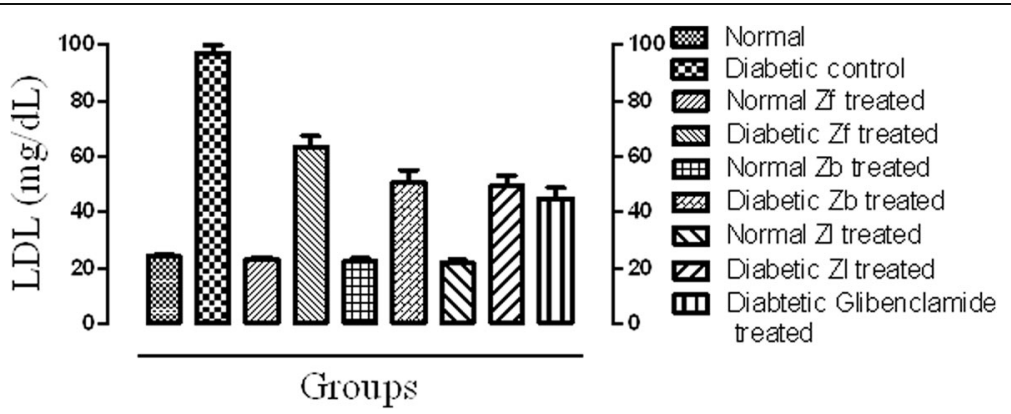

Fig. 3 Effect of extracts and standard drug on serum low density lipoproteins (mg/dl) level of normal and alloxan monohydrate induced diabetic mice 


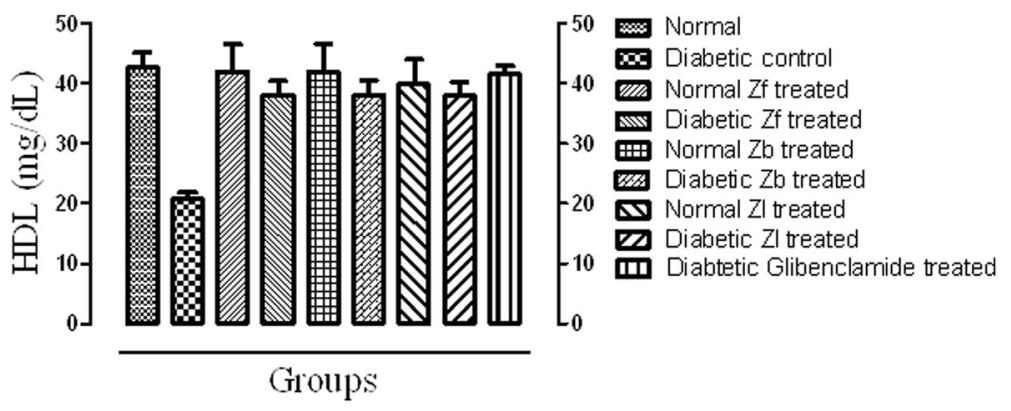

Fig. 4 Effect of extracts and standard drug on serum high density lipoproteins ( $\mathrm{mg} / \mathrm{dL}$ ) level of normal and alloxan monohydrate induced diabetic mice

provision can reduced the risk of vascular ailments by lowering the serum lipid concentration [33].In the normal conditions of metabolism insulin hydrolyses the triglycerides by activating the enzyme lipoprotein lipase. The deficiency in insulin results in inactivation of these enzymes thereby causing hyper-triglyceridemia. The researchers did report significant changes in lipid abnormalities [34].

The result of this study reveals that the dose of $500 \mathrm{mg} / \mathrm{kg}$ of each of $\mathrm{Zf}, \mathrm{Zb}$ and $\mathrm{Zl}$ recovered the level of serum TC and TG in a significant manner $(p<0.001)$ when compared with the diabetic control. The level of LDL, over a period of 15 days was significantly reduced $(p<0.001)$ towards normal as compared with diabetic control. However, the level of cardio protective lipid HDL was improved significantly by all the extracts in diabetic mice. The effect of extracts on HDL level of normal mice was not prominent. This shows hypolipidemic effect of the extracts and the significant reduction of serum lipid levels in diabetic mice after treatment with extracts may be directly attributed to improvements in insulin levels.

Various secondary metabolites isolated recently from medicinal plants have been shown to possess antidiabetic effect for example saponins [35], alkaloids [36] and flavonoids [37] and phenolic compounds can be responsible for the antidiabetic effect by preventing the destruction of $\beta$-cells by inhibiting the peroxidation chain reaction [38]. Our analysis of phytochemicals revealed the presence of such constituents in Z. armatum [39].

Increased serum levels of urea and creatinine, indicators of impaired renal function [40]. Diabetic control mice showed an increased level of creatinine and urea and this level remained elevated as compared with normal control when treated with extracts and standard over 15 days of treatment and showed little improvement towards normal control. In the present study, total $\mathrm{Hb}$ levels in diabetic control were reduced as compared with the normal control, which may be due to the formation of HbA1c (glycated hemoglobin). A previous report has indicated that, in diabetes, protein synthesis is decreased in all tissues, which is due to the relative deficiency of insulin and to depressed synthesis of $\mathrm{Hb}$ [41]. In the present study, treatment of diabetic mice with extracts ( $\mathrm{Zf}, \mathrm{Zb}$ and $\mathrm{Zl}$ ) resulted in a significant increase in $\mathrm{Hb}$ levels. This was more prominent in the $\mathrm{Zf}$ treated diabetic group. The effect of extracts on test for total proteins indicated a change in serum protein level of diabetic mice and a slight improvement was shown by the groups.

\section{Conclusion}

This study was conducted to explore the potential activity of extracts of plants Zanthoxylum armatum in normal and alloxan induced diabetic mice. Although all the extracts presented significant anti-diabetic activity in mice, but, leaves extract of $Z$. armatum was found most potent among the extracts. The extracts also showed improvement in other parameters studied like body weight, serum lipids (triglycerides, cholesterol, HDL and LDL). It is concluded that the methanol extract of Zanthoxylum armatum possesses significant antidiabetic activity and appears to be attractive materials for further studies and possible drug development.

\section{Abbreviations}

Hb: hemoglobin; HDL: high density lipoprotein; LDL: low density lipoprotein; TC: total cholesterol; TG: triglycerides; Z. armatum: Zanthoxylum armatum; Zb: bark of Zanthoxylum armatum; Zf: fruit of Zanthoxylum armatum; Zl: Leaf of Zanthoxylum armatum

Acknowledgements

Not applicable.

Funding

Not applicable

\section{Availability of data and materials}

The datasets used and/or analyzed in this study are available from the corresponding author, upon reasonable requests.

Authors' contributions

FA: Concept, design, literature search, lab work. QNS: definition of intellectual content, manuscript editing and manuscript review. MA: Enzyme inhibitory activity, manuscript review. All authors read and approved the final manuscript. 


\section{Ethics approval and consent to participate}

The approval of the Research, Ethical Committee (REC), department of Pharmacy, CIIT, Abbottabad was taken before the animal studies were conducted.

\section{Consent for publication}

Not applicable.

\section{Competing interests}

The authors declare that they have no competing interests.

\section{Publisher's Note}

Springer Nature remains neutral with regard to jurisdictional claims in published maps and institutional affiliations.

\section{Author details}

'Department of Pharmacy, COMSATS Institute of Information Technology, Abbottabad -22060, Pakistan. ${ }^{2}$ Department of Biochemistry and Biotechnology, The Islamia University of Bahawalpur, Bahawalpur -63100, Pakistan.

Received: 5 October 2017 Accepted: 13 February 2018

\section{Published online: 20 February 2018}

\section{References}

1. Jadhav R, Puchchakayala G. Hypoglycemic and antidiabetic activity of flavonoids: Boswellic acid, ellagic acid, quercetin, rutin on streptozotocinnicotinamide induced type 2 diabetic rats. Group. 2012;1:100g.

2. Ceylan S, Azal Ö, Taşlipinar A, Türker T, Açikel CH, Gulec M. Complementary and alternative medicine use among Turkish diabetes patients. Compl Ther Med. 2009:17(2):78-83.

3. World Health Organization. Annex, II-Guidelines for the Assessment of Herbal Medicines (WHO Technical Report Series No. 863). Geneva; 1996.

4. Shruthi A, Latha K, Vagdevi H, Pushpa B, Shwetha C. Anti-diabetic activity of the leaves extracts of Wrightia Tinctoria on alloxan induced diabetic rats. J Chem \& Pharm Res. 2012;4(6):3125-8.

5. Grover J, Yadav S, Vats V. Medicinal plants of India with anti-diabetic potential. J Ethnopharmacol. 2002;81(1):81-100.

6. Eddouks M, Lemhadri A, Michel J-B. Caraway and caper: potential antihyperglycaemic plants in diabetic rats. J Ethnopharmacol. 2004;94(1):143-8.

7. Musabayane C, Bwititi P, Ojewole J. Effects of oral administration of some herbal extracts on food consumption and blood glucose levels in normal and streptozotocin-treated diabetic rats. Methods Find Exp Clin Pharmacol. 2006;28(4):223-8.

8. Collier E, Watkinson A, Cleland CF, Roth J. Partial purification and characterization of an insulin-like material from spinach and Lemna gibba G3. J Biol Chem. 1987;262(13):6238-47.

9. Alarcon-Aguilara F, Roman-Ramos R, Perez-Gutierrez S, Aguilar-Contreras A, Contreras-Weber C, Flores-Saenz J. Study of the anti-hyperglycemic effect of plants used as antidiabetics. J Ethnopharmacol. 1998;61(2):101-10.

10. Mi B, Jelani G, Ahmad I. Leaf, Stem Bark And fruit anatomy of Zanthoxylum armatum dc.(Rutaceae). Pak J Bot. 2014;46(4):1343-9.

11. Singh TP, Singh OM. Phytochemical and pharmacological profile of Zanthoxylum armatum DC. - an overview. Indian J Nat Prod Res. 2011;2(3):275-85.

12. Rynjah CV, Devi NN, Khongthaw N, Syiem D, Majaw S. Evaluation of the antidiabetic property of aqueous leaves extract of Zanthoxylum armatum DC Using in vivo and in vitro approaches. J Trad Compl Med. 2018;8(1):134-40.

13. Karki H, Upadhayay K, Pal H, Singh R. Antidiabetic potential of Zanthoxylum armatum bark extract on streptozotocin-induced diabetic rats. Intern J Green Pharm (IJGP). 2014:8(2):77.

14. Matsui T, Yoshimoto C, Osajima K, Oki T, Osajima Y. In vitro survey of a-glucosidase inhibitory food components. Biosci Biotechnol Biochem. 1996;60(12):2019-22.

15. Weir GC, Bonner-Weir S. Five stages of evolving beta-cell dysfunction during progression to diabetes. Diabetes. 2004;53(suppl 3):S16-21.

16. Ou Y, Lin L, Yang X, Pan Q, Cheng X. Antidiabetic potential of phycocyanin: effects on KKAy mice. Pharm Biol. 2013;51(5):539-44.

17. Council NR. Guide for the care and use of laboratory animals. Washington DC: National Academy Press; 1996.

18. Phuong M, Ali B, Aziz E, Abdellatif S, Yahia C, Pierre S. The petroleum ether extract of Nigella sativa exerts lipid lowering and insulin-sensitizing action in the rats. J Ethnopharmacol. 2004;94:251-9.
19. Burtis CA, Ashwood ER, Bruns DE. Tietz textbook of clinical chemistry and molecular diagnostics. Elsevier Health Sciences. 2012;

20. Thomas L, Whicher JT, Andert SE: Clinical laboratory diagnostics: use and assessment of clinical laboratory results: TH-books; 1998.

21. Zaia DA, Marques FR, Zaia CT. Spectrophotometric determination of total proteins in blood plasma: a comparative study among dye-binding methods. Braz Arch Biol Technol. 2005:48(3):385-8.

22. Burstein M, Scholnick H, Morfin R. Rapid method for the isolation of lipoproteins from human serum by precipitation with polyanions. J Lipid Res. 1970;11(6):583-95.

23. Salimifar M, Fatehi-Hassanabad Z, Fatehi M. A review on natural products for controlling type 2 diabetes with an emphasis on their mechanisms of actions. Curr Diab Rev. 2013;9(5):402-11.

24. Shapiro K, Gong WC. Natural products used for diabetes. J Amer Pharm Assoc. 2002:42(2):217-26.

25. Ya M, Umamageswari M, Karthikeyan T. Evaluation of Antihyperglycemic activity of aqueous extract of leaves of. Solanum Nigrum. Int J Pharm Bio Sci. 2012:312-9.

26. Karan SK, Mishra SK, Pal D, Mondal A. Isolation of $\beta$-sitosterol and evaluation of antidiabetic activity of Aristolochia indica in alloxan-induced diabetic mice with a reference to in-vitro antioxidant activity. J Med Plants Res. 2012:6(7):1219-23.

27. Prisilla DH, Balamurugan R, Shah HR. Antidiabetic activity of methanol extract of Acorus calamus in STZ induced diabetic rats. Asian Pac J Trop Biomed. 2012;2(2):S941-6.

28. Pari L, Latha M. Protective role of Scoparia dulcis plant extract on brain antioxidant status and lipidperoxidation in STZ diabetic male Wistar rats. BMC Compl Altern Med. 2004;4(1):16.

29. Sezik E, Aslan M, Yesilada E, Ito S. Hypoglycaemic activity of Gentiana olivieri and isolation of the active constituent through bioassay-directed fractionation techniques. Life Sci. 2005;76(11):1223-38.

30. Slei A. Effects of Zanthoxylum zanthoxyloides leaves on blood glucose, lipid profile and some liver enzymes in alloxan induced diabetic rats. Intern J Sci Nat. 2012;3(3):497-501.

31. Gao H, Huang Y-N, Gao B, Xu P-Y, Inagaki C, Kawabata J. a-glucosidase inhibitory effect by the flower buds of Tussilago farfara L. Food Chem. 2008:106(3):1195-201.

32. Balfour JA, McTavish D. Acarbose. Drugs. 1993;46(6):1025-54.

33. Sikarwar M, Patil M. Antidiabetic activity of Pongamia pinnata leaf extracts in alloxan-induced diabetic rats. Intern J Ayur Res. 2010;1(4):199.

34. Luo Q, Cai Y, Yan J, Sun M, Corke H. Hypoglycemic and hypolipidemic effects and antioxidant activity of fruit extracts from Lycium barbarum. Life Sci. 2004;76(2):137-49.

35. Koneri RB, Samaddar S, Ramaiah CT. Antidiabetic activity of a triterpenoid saponin isolated from Momordica cymbalaria Fenzl. Indian J Exp Biol. 2014:52:46-52.

36. Tiong SH, Looi CY, Hazni H, Arya A, Paydar M, Wong WF, Cheah S-C, Mustafa MR, Awang K. Antidiabetic and antioxidant properties of alkaloids from Catharanthus roseus (L.) G. Don. Molecules. 2013;18(8):9770-84.

37. Salib JY, Michael HN, Eskande EF. Anti-diabetic properties of flavonoid compounds isolated from Hyphaene thebaica epicarp on alloxan induced diabetic rats. Pharm Res. 2013;5(1):22

38. Oboh G, Ogunsuyi OB, Ogunbadejo MD, Adefegha SA. Influence of gallic acid on a-amylase and a-glucosidase inhibitory properties of acarbose. $J$ Food Drug Anal. 2016;24(3):627-34

39. Alam F. QN US: Pharmacognostic study and development of quality control parameters for fruit, bark and leaf of Zanthoxylum armatum (Rutaceae). Anc Sci Life. 2015;34(3):148

40. Gerbes A, Gülberg V, Bilzer M, Vogeser M. Evaluation of serum cystatin C concentration as a marker of renal function in patients with cirrhosis of the liver. Gut. 2002;50(1):106-10.

41. Nabeel MA, Kathiresan K, Manivannan S. Antidiabetic activity of the mangrove species Ceriops decandra in alloxan-induced diabetic rats. J Diab. 2010:2(2):97-103. 